\title{
PENGENALAN JEMURAN IKAN ASIN OTOMATIS BERBASIS MIKROKONTROLLER UNTUK INDUSTRI KECIL MENENGAH (IKM) IKAN ASIN DI KECAMATAN TEGAL BARAT
}

\author{
Rais $^{1}$, Arfan Haqiqii ${ }^{2}$, Yerry Febrian Sabanise ${ }^{3}$, Miftakhul Huda ${ }^{4}$, Doni Firstanto ${ }^{5}$ \\ ${ }^{12345}$ Program Studi DIII Teknik Komputer, Politeknik harapan Bersama \\ e-mail :'rais.hojawa@gmail.com, ${ }^{2}$ arfan.hqq@gmail.com, ${ }^{3}$ yerryfebrian@gmail.com, \\ ${ }^{4}$ mh_iftah@yahoo.com,
}

\begin{abstract}
Abstrak
Pada proses pengeringan akan mengalami kesulitan apabila pada saat dikeringkan tibatiba hujan, ikan asin tidak dapat langsung diamankan seketika. , hal ini menyebabkan ikan asin akan terkena air hujan yang akan mempengaruhi proses pengeringan dan mengurangi kualitas ikan sendiri yang menyebabkan kerugian pada pelaku industri. Dengan keadaan yang sering dialami pelaku industri tersebut, kami bermaksud untuk membuat inovasi pada jemuran ikan asin yang selama ini masih dilakukan secara manual dan membutuhkan tenaga manusia. Dengan cara membuat pengembangan prototype jemuran ikan asin otomatis menggunakan teknologi mikrokontroler Arduino, maka jemuran ikan asin dapat dikontrol dengan program Arduino. Saat ini penerapan sensor untuk mempermudah pekerjaan manusia semakin meningkat. Salah satunya ialah penggunaan sensor LDR dan Sensor Hujan yang di aplikasikan pada prototype jemuran ikan asin otomatis. Mikrokontroler Arduino akan menerima sinyal dari sensor tersebut, lalu memberikan perintah pada Motor-DC untuk menggerakan atap prototype pada kondisi tertentu.
\end{abstract}

Kata kunci: Prototype, sensor LDR, Sensor Hujan, Arduino Uno.

\section{PENDAHULUAN}

Pemanfaatan sumber daya alam bagi keberlangsungan kehidupan manusia sampai saat ini masih menjadi pilihan utama. Salah satu sumber daya alam utama yang menjadi penopang dalam melakukan aktifitas sehari-hari yaitu cahaya matahari. Banyak sekali kegiatan manusia yang memanfaatkan cahaya matahari untuk membantu menyelesaikan pekerjaan. Misalkan saja pemanfaatan cahaya matahari dalam industri pembuatan garam, mengeringkan ikan asin, atau dalam skala rumahan seperti mengeringkan pakaian. Namun ketergantungan ini justru dapat menjadi penghambat bagi kegiatan manusia ketika alam sedang dalam keadaan yang berubahubah. Ketika cuaca sedang tidak stabil kegiatan-kegiatan tersebut dapat terhambat atau bahkan terhenti. 
Ikan merupakan sumber bahan pangan yang memiliki protein yang tinggi dibandingkan sumber protein hewan lainnya. Protein pada ikan sangat baik untuk mendukung kesehatan karena asam amino pada ikan mirip dengan asam amino yang terdapat pada tubuh manusia. Selain itu, ikan merupakan salah satu sumber protein hewani yang banyak dikonsumsi masyarakat, mudah didapat, dan harganya murah dibandindingkan dengan sumber protein dari hewan lainnya.

Seiring meningkatnya produksi dalam sektor perikanan, maka permintaan untuk ikan segar semakin meningkat. Sehingga ikan-ikan yang sudah ditangkap akan ditangani sebaik mungkin agar tetap memiliki kualitas yang baik sampai ke tangan konsumen, tetapi tidak sedikit pula ikan yang salah dalam penangannya sehingga mengalami penurunan kualitas. Sehingga harga jual semakin rendah sehingga para pengrajin atau industri kecil ikan asin tidak mendapatkan keuntungan yang seharusnya didapatkan. Permasalahan di atas dapat diatasi dengan dilakukannya penanganan saat pengeringan ikan asin.

Proses pengeringan yang baik merupakan salah satu cara untuk menjaga kualitas ikan dari berbagai macam hal yang kemungkinan terjadi seperti terjadi hujan mendadak saat ikan asin dijemur, dimakan binatang seperti kucing anjing dan kecoa atau dimakan semut selain itu debu yang menempel pada ikan asin dapat menurunkan kualitas dari tingkat kebersihan ikan tersebut.

Masyarakat di Kecamatan Tegal Barat sebagaian besar adalah nelayan dan pengrajin atau IKM ikan asin. Hampir setiap hari masyarakat di daerah tersebut menjemur ikan asin namun masyarakat di sekitar melakukan proses pengerikan ikan asin hanya menggunakan jaring ikan, tikar ada juga yang menggunakan jalan raya sebagai tempat untuk menjemur ikan sehingga mengakibatkan penurunan kualitas dari ikan asin.

Minimnya pengetahuan dan pemahaman para nelayan dan IKM ikan asin akan penggunaan teknologi sangat kurang sekali. Padahal pemanfaatan teknologi dalam proses penjemuran ikan asin sangat bermanfaat sekali untuk menjaga agar ikan asin kualitasnya tetap terjaga. Permasalahan yang terjadi pada nelayan dan IKM ikan asin kurangnya pengetahuan akan pemanfaatan teknologi dalam penjemuran ikan asin. Sehingga pengabdian masyarakat ini akan mengambil tema sosialisasi pemanfaatan jemuran ikan asin otomatis berbasis mikrokontroller untuk para pengrajin ikan asin di kecamatan tegal barat dengan tujuan agar para nelayan dan IKM ikan asin di Kecamatan Tegal Barat lebih mengerti bagaimana pemanfaatan teknologi dalam menjemur ikan asin agar kualitas dari ikan asin tetap terjaga. 


\section{METODE}

\subsection{Sasaran Kegiatan}

Kegiatan pengabdian masyarakat yang dilakukan di bebrapa kelurahan yang mayoritas masyarakatnya adalah pelaku Industri Kecil Menengah (IKM) ikan asin yang merupakan salah satu sasaran bagi Prodi DIII Teknik Komputer. Khalayak sasaran yang dipilih adalah pelaku UKM ikan asin di Kelurahan Muarareja Kecamatan Tegal Barat Kota Tegal

\subsection{Metode Kegiatan}

Kegiatan berupa workshop pengenalan jemuran ikan asin otomatis berbasis mikrokontroller untuk Industri Kecil Menengah (IKM) ikan asin di Kecamatan Tegal Barat dibagi menjadi 2 sesi. Sesi pertama menyampaikan materi tentang cara membuat jemuran ikan asin serta komponen apa saja yang ada, sesi yang kedua mendemontrasikan/mempraktikan jemuran ikan asin jika terjadi hujan atau saat cuaca mendung.

\subsection{Kerangka Pemecahan Masalah}

Alternatif pemecahan masalah dilakukan dengan mengadakan workshop pengenalan jemuran ikan asin otomatis berbasis mikrokontroller untuk Industri Kecil Menengah (IKM) untuk masyarakat Kelurahan Muarareja. Peserta masih banyak yang menjemur ikan di sembarang tempat sehingga mengurangi kualitas dari ikan asin tersebut, sehingga perlu terobosan baru untuk dapat menjemur ikan secara otomatis agar terhindar dari hujan dan binatang buas. Dengan metode pengenalan ini mampu memberikan pemahaman tentang cara merancang jemuran ikan asin otomatis pada kegiatan PKM

\section{HASIL DAN PEMBAHASAN}

\subsection{Persiapan}

Sebelum kegiatan dilaksanakan maka dilakukan persiapan-persiapan sebagai berikut:

a. Melakukan studi pustaka jenis-jenis PKM bagi peserta

b. Mempersiapkan alat untuk membantu menyelesaikan permasalahan PKM.

c. Menentukan waktu pelaksanaan dan lamanya kegiatan pengabdian masyarakat.

\subsection{Pelaksanaan Kegiatan}

Pelaksanaan PKM dilaksanakan selama 2 hari Kamis s/d Jum'at tanggal 21 s/d 22 Maret 2019, waktu dari jam 10.00 s.d selesai bertempat di Kelurahan Muarareja Kecamatan tegal Barat. Kegiatan ini dilaksanakan 2 pertemuan yakni pemaparan teori dan praktikum/domontrasi. 
Kegiatan ini dilakukan oleh dosen dan mahasiswa semester 2 dan 4 dengan jumlah mahasiswa sebanyak 10 orang. Kegiatan ini berjalan dengan baik dan lancar.

\section{A. Kegiatan Workshop}

Pada pengabdian masyarakat di Kelurahan Muarareja kecamatan Tegal Barat diberikan workshop tentang jemuran ikan asin otomatis. Alasan mengapa jemuran ikan asin otomatis karena mayoritas masyarakat di Muarareja sebagai nelayan dan pelaku IKM ikan asin sehingga dengan memberikan workshop ini diharapkan dapat :

a. Memberikan pemahaman dan pengetahuan terhadap perkembangan Internet of Things dalam dunia industri

b. Meningkatkan pola fikir pelaku IKM ikan asin dalam meningkatkan kualitas dan kuantitas dari ikan asin

c. Meningkatkan kinerja pelaku IKM ikan asin, dalam upaya untuk perbaikan atau inovasi dalam peningkatan produki

d. Pengenalan jemuran ikan asin ini untuk meningkatkan mutu melalui suatu kajian yang ada dalam dunia produksi atau pengolahan

e. Dengan adanya kegiatan PKM ini akan menjadikan kreatifitas pelaku IKM ikan asin untuk dapat bersaing dengan pelaku IKM lainya dalah hal kualitas produksi.

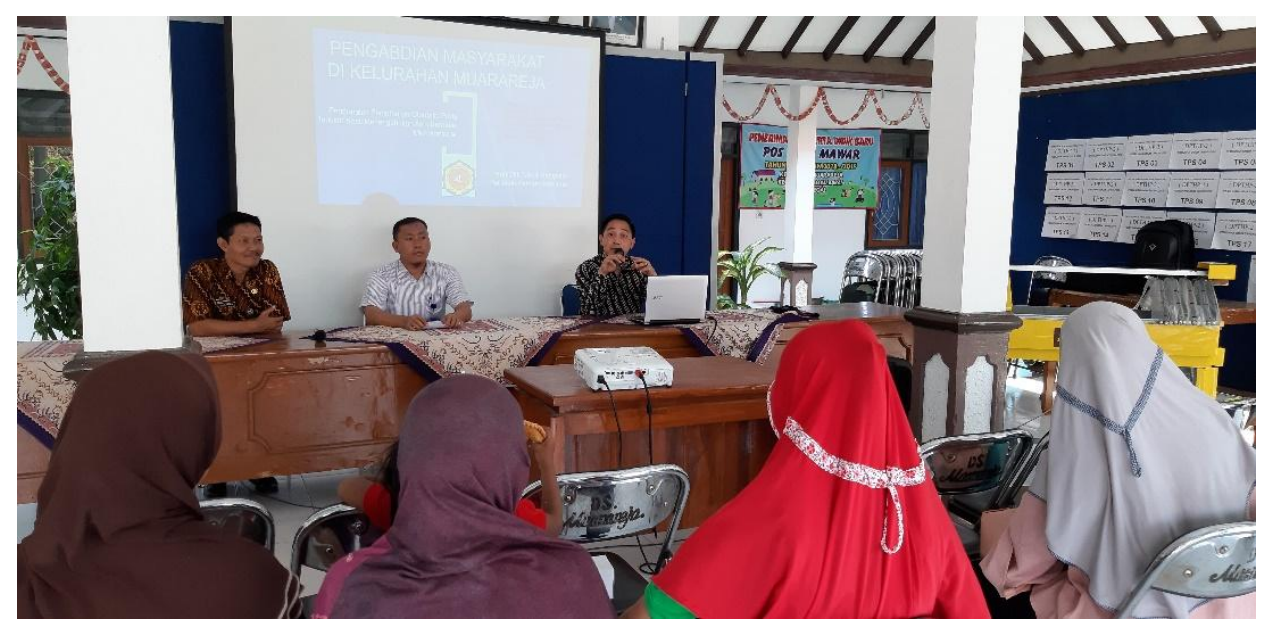

Gambar 1 Pemberian materi kepada peserta 


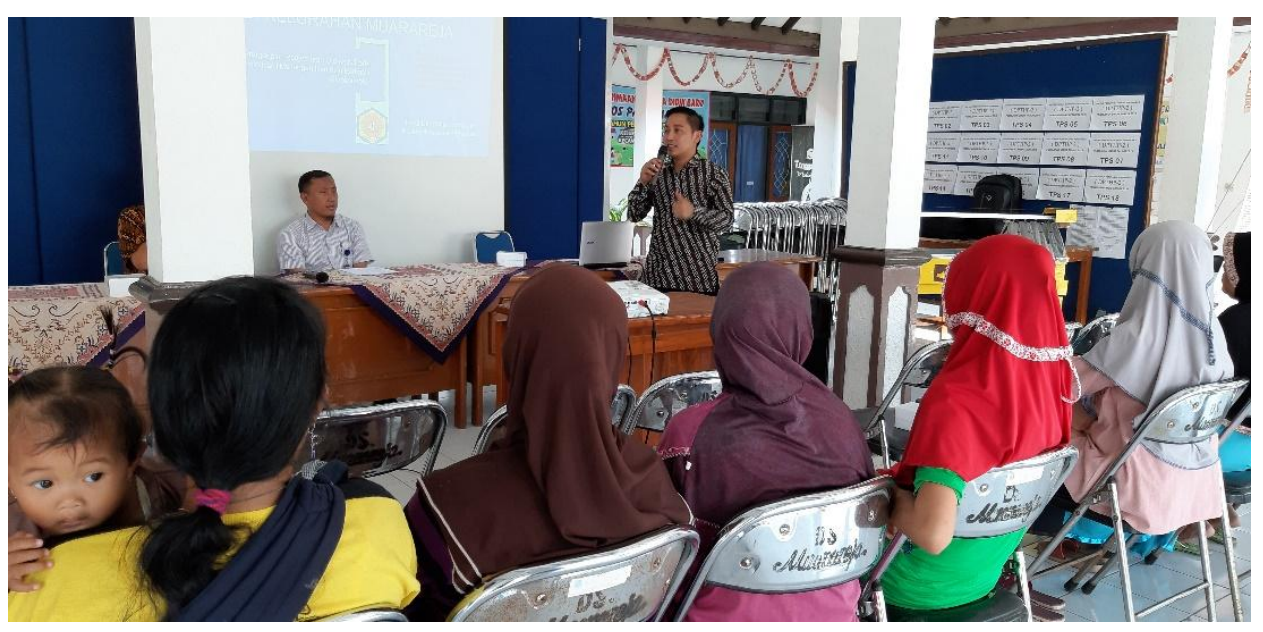

Gambar 2 Pemberian materi kepada peserta

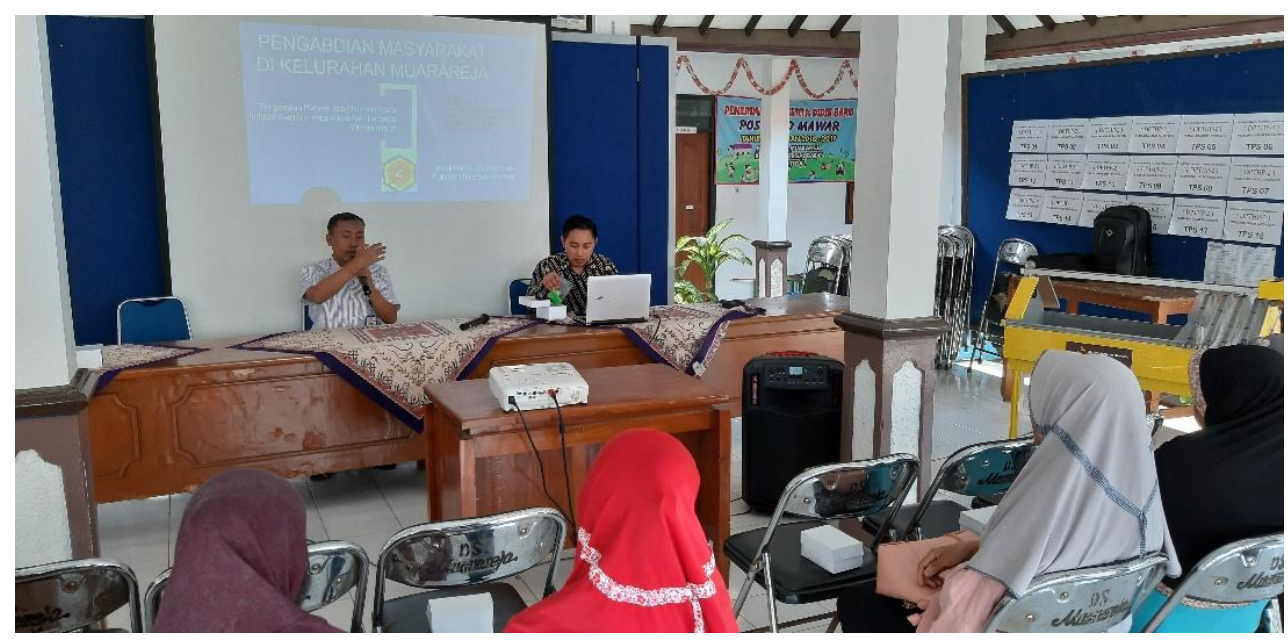

Gambar 3 Pemberian materi kepada peserta

\section{B. Pengenalan alat jemuran ikan asin}

Dalam workshop pengenalan jemuran ikan asin otomatis ini peserta dikenalkan terkait komponen komponen apa saja yang digunakan sehingga terbentuk sebuah jemuran ikan otomatis yang dapat menutup ketika terjadi hujan dan ketika akan malam hari. Serta diberikan pemahaman bahwa jemuran otomatis ini dapat meningkatkan kualitas ikan asin serta meringankan beban pekerjaan pelaku IKM dalam menjemur ikan asin karena tidak perlu lahan yang luas untuk dapat menjemur ikan asin dalam volum yang besar. 


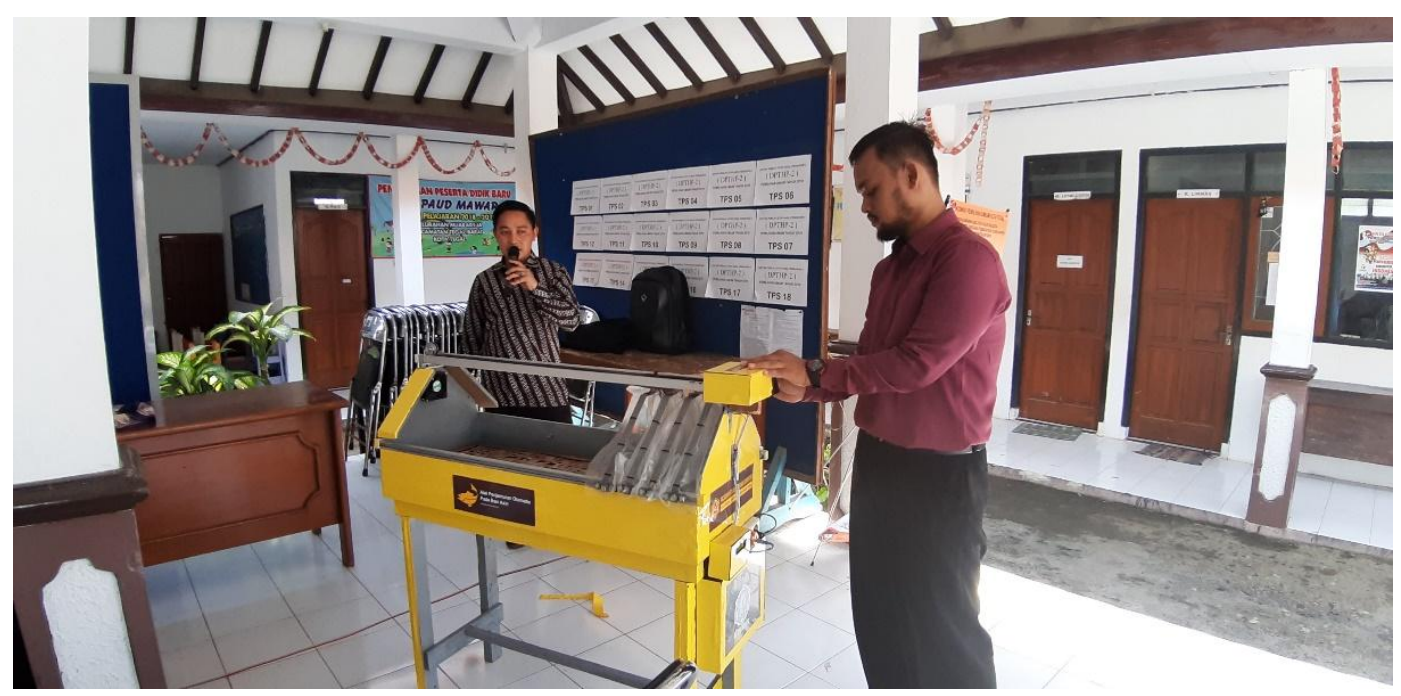

Gambar 4 pengenalan alat jemuran ikan asin

\section{Capaian Kegiatan}

Workshop pengenalan jemuran ikan asin merupakan hal yang baru bagi pelaku IKM ikan asin di Kelurahan Muarareja Kecamatan Tegal Barat. Berdasarkan wawancara dan Tanya jawab langsung selama kegiatan Pengabdian Masyarakat di Kelurahan Muarareja memberikan hasil sebagai berikut :

a. Memberikan pengetahuan para pelaku IKM untuk dapat menjemur ikan asin agar terjaga kualitasnya.

b. Meningkatkan pengetahuan akan keterampilan cara membuat jemuran ikan asin otomatis

c. Melatih pemikiran kreatif para pelaku IKM industri ikan asin untuk meningkatkan produksinya

\subsection{Evaluasi Kegiatan}

Untuk mencapai target tujuan pelatihan ini, maka pada evaluasi kegiatan peserta diberikan diberikan kesempatan untuk bertannya serta meminta masukan dari peserta terkait pelaksanakan kegiata pengabdian masyarakat ini. Serta menanyakan sejauh mana manfaat yang diperoleh dari kegiatan ini untuk dapat meningkatkan kualitas dari produksi ikan asin. 


\section{KESIMPULAN}

Dari kegiatan pengabdian masyarakata yang dilakukan dapat disimpulkan bahwa

a. Menambah pemahaman dan pengetahuan tentang pemanfaatan teknologi dalam dunia industri, terutama pada proses pengerikan ikan secara otomatis

b. Menumbuh kembangkan ide kreatif mahasiswa untuk menemukan hal yang baru untuk dijadikan sebuah karya tulis

c. Meningkatkan pengetahuan dan wawasan pelaku IKM ikan asin dalam menjaga kualitas produksinya.

\section{SARAN}

Mengingat besarnya manfaat kegiatan pengabdian ini baik buat, masyarakat, dosen dan mahasiswa, maka selanjutnya perlu :

a. Adanya pengabdian berkelanjutan, agara kualitas dari produk yang dihasilkan industri terjaga kualitasnya.

b. Waktu kegiatan pengabdian diperpajang agara semua materi dapat disampaikan.

\section{UCAPAN TERIMA KASIH}

Pada kesempatan ini kami mengucapkan terimakasih kepada:

1. Pusat Penelitian dan Pengabdian Masyarakat (P3M) Politeknik Harapan Bersama Tegal yang sudah mendanai kegiatan PKM ini untuk tahun pelaksanaan anggaran tahun 2019.

2. Kecamatan Tegal Barat dan Kelurahan Muaraeja sebagai mitra kami atas dukungannya sehingga kegiatan ini berjalan lancar

3. Seluruh peaku IKM/UKM Ikan asin di Kelurahan Muarareja yang sudah datang dan mengikuti kegiatan ini.

\section{DAFTAR PUSTAKA}

[1] Suryana. 2010. Buku Ajar Metodologi Penelitian, Model Praktis Penelitian Kuantitatif dan Kualitatif. Bandung: Universitas Pendidikan Indonesia 
[2] Rismawan, Eko. 2012." Jurnal Informatika dan Teknik Elektro Terapan"Jurusan Teknik Elektro Fakultas Teknik Universitas Lampung.

[3] Suhartini, S dan N. Hidayat. 2005. Olahan Ikan Segar. Surabaya: Penerbit Trubus Agrisarana.

[4] Sumisjakartono, 1987. Elektronika Praktis untuk pemula, hobbyist, dan wiraswatawan, PT Elex Media Komputindo.

[5] Syahwil, Mohammad. 2013. "Panduan Mudah Simulasi dan Pratek Mikrokontroler Arduino". Yogyakarta : ANDI.

[6] Kusuma, Hendra. 2013. Rancangan Bangun Pengendalian Komunikasi Serial Menggunakan Mikrokontroler.Skripsi.STMIK Atmaluhur. Pangkalpinang 